\title{
The Effect of the Kinetic Sensory Activities Program and its Relationship with the Acquisition of the Blind Child Concept of Body Image
}

\section{"Dr/ Alia Abdel Moneim Ibrahim}

\section{Introduction and research problem}

In these modern times, motor education is no longer means just a means of playing and recreation, but it has become one of the basic needs of the child's life.

Jihan

Abdel-Fattah (2001) points out that it has increased the interest of all educational and social institutions for children to reach the opportunities for growth and learning.

This concern has not been confined to normal children, but has expanded in recent years to include children with special needs, The community, but the visible children, live better than their blind peers because they enjoy all the senses, especially the sense of vision,

which is one of the most important senses to identify the elements of the environment around them and play, simulation and movement

freely, which helps them to grow, normalize and adapt any thing (2: 8 ) by a good way with themselves and with others.

Shaima Hassan and Mervat Salim (2003) agree that sense of sight loss is a disability that distinguishes the blind from the visual world, and here it has a significant impact on his relationships with all that surrounds him The blindness is not only the loss of part of the body, It's considered a major change to his life, So the blind must be prepared in a special way commensurate with his abilities in different fields of activity and the need to integrate him into normal life and the surrounding environment, and that the other senses remaining in the blind (Hearing- Touch) For any information to be received whether it relates to education

- Assistant Professor, Department of Basic Sciences, Faculty of Kindergarten, Fayoum University. 
Motor performance or correct the perception of what in his mind to perceived and felt and can be performed. (177: 11)

Shaima Hassan, Mervat Selim (2003), Fatima Fawzi (2004) and Jihan Abdul Fattah (2001), Ahmed Adam (2001), agree that the blind person is normal person but he may pay advantages The average person as much as he is dependent on his other senses. Physical education programs for the blind are based on the rest of the other senses (Hearing, Touch, Smell) (11: 177) (15: 251) $(8: 2,5)(2: 5,6)$

Iqbal Makhlouf (2004) states that cognitive-motor cognition is particularly important for both motor speed learning and compatibility in complex movements, And that the high accuracy of sensemotor perceptions increases the ability of the individual and the athlete to control and consciously guide the movement of the body as a whole in the space or his connections For each other, in addition to allowing for the recognition of negative movements or positive movements. $(6: 32,35)$

Mohammed Fahmy (2001), Awatif Ibrahim, Manal
Abdel Hadi, (2006).agreed that practice of the blind person for sports and motor activities helps them to develop some sensory aspects such as sense of distance and direction, sense of motor balance, sense of body position in the space, sense of perception These sensors may help him to identify the environment around him, as well as the ability to acquire the motor skills which he needs to move from one place to another and achieve his behavioral goals. (7:21) (178: 14)

Hussain Fayed (2004) states that the body image is concerned with "The weight and body shape of life experiences of adolescent females". These concerns include thinness as a good quality of life, dissatisfaction with weight gain and anxiety about weight gain, over- And weight loss versus personal messages about thinness. "(199: 9)

The researcher believes that the blind group has not received the attention required so far, the society's perception of them incomplete is limited to social and health care only, and within the researcher's knowledge that did not address 
the authorities responsible for that interest in the nursery in large format, in terms of providing programs and mobility commensurate With their special circumstances.

Evidence of this is that the motor education curricula applied to this stage (the blind category) do not take into account their health conditions, as well as the lack of a special curriculum for the blind education of the blind and the absence of teaching methods for the blind.

To know the impact of the activities of a sense of mobility program on the Acquisition of a blind child to the concept of body image.

Search goal

The aim of this research is to identify the effect of a kinetic activity program on the perception of the body image.

\section{Research hypotheses}

- There are statistically significant differences between the averages of pre and post measurements in the level of the concept of body image in blind children from (4-6) of the research sample.

-There were statistically significant differences between the averages of the pre and post measurements in the level of sensory perception in blind children (4-6).

\section{Research Plan and Procedures: Research Methodology:}

The researcher used the experimental approach using the experimental design of a single experimental group to suit the nature of the research and to achieve its goals and objectives.

\section{Research community:}

The research community was chosen from visually impaired children in the Hearts of Good Association in Fayoum governorate and the number of (30) children for the academic year 2015/2016.

\section{The research sample:}

The sample of the study was on the visually impaired children of Hearts of Good Association in the city of Fayoum for the AGE level (46) years.

The sample was chosen in a deliberate manner, and the number of (23) children used the researcher (15) children as a basic sample in addition to (8)

\section{Homogeneity of the research sample}

\section{Table (1)}


The MSA, AVERAGE, the standard deviation, and the torsion coefficient of the variables under consideration Visually impaired children $(\mathbf{N}=\mathbf{2 3})$

\begin{tabular}{c|c|c|c|c|c}
\hline \hline Variables & $\begin{array}{c}\text { Unit } \\
\text { measurement }\end{array}$ & Average & Mean & $\begin{array}{c}\text { standard } \\
\text { deviation }\end{array}$ & $\begin{array}{c}\text { Torsion } \\
\text { coefficient }\end{array}$ \\
\hline \hline
\end{tabular}

Growth rates

\begin{tabular}{|c|c|c|c|c|c|}
\hline Age & Year & 0.11 & 0.1 & $\cdot r \varepsilon$ &..$M T I$ \\
\hline Height & $\mathrm{Cm}$ & $91.0 \mathrm{r}$ & 91.0. & $\cdot . \leqslant 1$ & 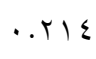 \\
\hline Wight & $\mathrm{Kg}$ & r. T. & rI.r. & . Ir & .700 \\
\hline
\end{tabular}

Body image scale

\begin{tabular}{|c|c|c|c|c|c|}
\hline $\begin{array}{c}\text { Body image } \\
\text { Aware }\end{array}$ & Degree & IV.OY & IV.O. & - I T & . \\
\hline $\begin{array}{l}\text { The image of } \\
\text { the social body }\end{array}$ & Degree & ro. \& & ro. \&. & $.1 \leqslant$ & $. .1 \leq$ \\
\hline $\begin{array}{c}\text { Emotional body } \\
\text { image }\end{array}$ & Degree & $1 \wedge .1$. & $1 \wedge . .$. & . & דr. \\
\hline $\begin{array}{l}\text { Total score of } \\
\text { the scale }\end{array}$ & Degree & $71 . .4$ & 7.9. & $.7 V$ & $.0 Y$ \\
\hline
\end{tabular}

Psychometric Perceptual Scale

\begin{tabular}{|c|c|c|c|c|c|}
\hline $\begin{array}{l}\text { Auditory } \\
\text { perception }\end{array}$ & Degree & $r . r 1$ & r.r. &.$r \varepsilon$ & . Ir \\
\hline $\begin{array}{c}\text { Tactile } \\
\text { perception }\end{array}$ & Degree & T.ro & r.r. & 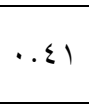 & $\cdot \varepsilon \leqslant 1$ \\
\hline $\begin{array}{c}\text { Understanding } \\
\text { movement and trends }\end{array}$ & Degree & $T . Y \varepsilon$ & T.T. & . Ir & .ro \\
\hline $\begin{array}{l}\text { Understanding } \\
\text { sizes, weights } \\
\text { and lengths }\end{array}$ & Degree & r.11 & r.1. & $0.1 \varepsilon$ &. $.1 \mathrm{~V}$ \\
\hline $\begin{array}{l}\text { Total score of } \\
\text { the scale }\end{array}$ & & $\mid\{. \Lambda \mid$ & $1 \leqslant . V$. & $\therefore V V$ & אות. \\
\hline
\end{tabular}

It is clear from Table (1) that the values of the convolution coefficients for the variables of growth rates and the body image scale, and the sense of kinetics in the study sample ranged from $( \pm 3)$ indicating to the moderation of the sample distribution in these variables.

Data collection tools:

Assiut Journal For Sport Science Arts 
The researcher used the

First: The standards used

following tools:

\begin{tabular}{|l|l|}
\hline $\begin{array}{l}1-\text { measure the body image of } \\
\text { the visually impaired }\end{array}$ & $\begin{array}{l}\text { Prepared by: Eman Fouad El } \\
\text { Kashef. (2010) (7) }\end{array}$ \\
\hline $\begin{array}{l}2-\text { the measure of sensory } \\
\text { perception of the blind }\end{array}$ & $\begin{array}{l}\text { Prepared by Zainab Mahmoud } \\
\text { Shuqair (2011) (10) }\end{array}$ \\
\hline $\begin{array}{l}\text { 3- The proposed sensory motor } \\
\text { program. }\end{array}$ & Preparation by / Researcher \\
\hline
\end{tabular}

\section{Proposed Program:}

The researcher reviewed several previous studies which related to the field of this research $(12,16,18,19,23$, 24) and to explore the views of many specialized professors, whose names are attached (1) The components of the program in line with the age of children, and with the type of disability, and in light of their abilities and needs.

\section{Program Goals :}

The program aims to:

- Improving the concept of the body image of the child with visual impairment.

- Improving the sensory level of the child with visual impairment

\section{Duration of the proposed} program:

The implementation of the program (8) took twelve weeks, and the education was three (3) weekly. The total number of units of the program (24) was twenty-four units (5) and the unit time was 50

minutes, : -

\begin{tabular}{|l|l|}
\hline Small games & $20 \mathrm{~min}$ \\
\hline Kinetic sensory games. & $20 \mathrm{~min}$ \\
\hline Relax & $10 \mathrm{~min}$ \\
\hline Total time & $50 \mathrm{~min}$ \\
\hline
\end{tabular}

View and discuss the results: 
Table (2)

"The significance of the differences between the pre and post Measurement in the level of the body image scale The visually impaired child has a " N = 15

\begin{tabular}{|c|c|c|c|c|c|c|c|c|c|}
\hline \multirow{2}{*}{ Variables } & \multirow{2}{*}{$\begin{array}{l}\text { Measurement } \\
\text { unit }\end{array}$} & \multicolumn{2}{|c|}{$\begin{array}{l}\text { Pre } \\
\text { measurement }\end{array}$} & \multicolumn{2}{|c|}{$\begin{array}{l}\text { Post } \\
\text { measurement }\end{array}$} & \multirow{2}{*}{$\begin{array}{l}\text { Differences } \\
\text { Between } \\
\text { The } \\
\text { average }\end{array}$} & \multirow[t]{2}{*}{$\begin{array}{l}\text { Improvement } \\
\text { rate }\end{array}$} & \multirow[t]{2}{*}{$\begin{array}{l}\mathrm{T} \\
\text { value }\end{array}$} & \multirow[t]{2}{*}{$\begin{array}{l}\text { Level of } \\
\text { significance }\end{array}$} \\
\hline & & M & E & M & E & & & & \\
\hline $\begin{array}{l}\text { Body } \\
\text { image } \\
\text { Aware }\end{array}$ & Degree & IV.or & .rr & $r 1.70$ & ..$r 4$ & $11.1 \%$ & \%тr.or & $\varepsilon . \Lambda_{0}$ & Indicated \\
\hline $\begin{array}{l}\text { The image } \\
\text { of the } \\
\text { social body }\end{array}$ & Degree & ro.s & $0.1 \leqslant$ & rv.10 & $\therefore$. v & $11 . v \varepsilon$ & $\%$ \% т.т. & $\varepsilon .7 T$ & Indicated \\
\hline $\begin{array}{l}\text { Emotional } \\
\text { body } \\
\text { image }\end{array}$ & Degree & 11.1. & D.rT & rv. 70 & . .or & 9.00 & \%or.ve & ๕. ๕ & Indicated \\
\hline $\begin{array}{l}\text { Total score } \\
\text { of the scale }\end{array}$ & Degree & $71 . .4$ & . IV & $9 r . \leqslant 0$ &. .91 & rT.ST & \%or.ir & $\varepsilon .01$ & Indicated \\
\hline
\end{tabular}

* Tabular value $(\mathrm{T})$ at significance level $(0.05)=1.796$

Table (2) shows that there are statistically significant differences between the averages of the pre and post measurements at the level

Table (3) of the body image scale for visually impaired persons. The sample value $(\mathrm{T})$ was greater than the tabular value at the significance level (0.05).

\section{"The significance of the differences between the pre and post measurement at the level of cognitive measure of sense The visually impaired child has a " $N=15$}

\begin{tabular}{|c|c|c|c|c|c|c|c|c|c|}
\hline \multirow{2}{*}{ Variables } & \multirow{2}{*}{$\begin{array}{l}\text { Measurement } \\
\text { unit }\end{array}$} & \multicolumn{2}{|c|}{$\begin{array}{l}\text { Pre } \\
\text { measurement }\end{array}$} & \multicolumn{2}{|c|}{$\begin{array}{l}\begin{array}{l}\text { Post } \\
\text { measurement }\end{array} \\
\end{array}$} & \multirow{2}{*}{$\begin{array}{l}\text { Differences } \\
\text { Between } \\
\text { The } \\
\text { average }\end{array}$} & \multirow[t]{2}{*}{$\begin{array}{l}\text { Improvement } \\
\text { rate }\end{array}$} & \multirow[t]{2}{*}{$\begin{array}{l}\mathrm{T} \\
\text { value }\end{array}$} & \multirow[t]{2}{*}{$\begin{array}{l}\text { Level of } \\
\text { significance }\end{array}$} \\
\hline & & $\mathrm{M}$ & E & $\mathrm{M}$ & E & & & & \\
\hline $\begin{array}{l}\text { Auditory } \\
\text { perception }\end{array}$ & Degree & $r . r)$ &.$r \varepsilon$ & 7.1. & $\quad \cdots 1 \varepsilon$ & r.A9 & $\% q . . . r$ & r.11 & Indicated \\
\hline $\begin{array}{l}\text { Tactile } \\
\text { perception }\end{array}$ & Degree & r.ro & . \& & $7.1 \%$ & $\therefore r$ & r.AV & $\%$ \%л.r. & r.ro & Indicated \\
\hline $\begin{array}{l}\text { Understanding } \\
\text { movement } \\
\text { and trends }\end{array}$ & Degree & T.TE & .rr & $1, .11$ & . $r r$ & r.Av & $\% \pi r . .1$ & r.tr & Indicated \\
\hline $\begin{array}{l}\text { Understanding } \\
\text { sizes, weights } \\
\text { and lengths }\end{array}$ & Degree & r.11 & $\cdots 1 \varepsilon$ & $\varepsilon \ldots$ & $\cdot . \wedge \varepsilon$ & $1.9 \leqslant$ & $\% 91.9 \leq$ & r.IV & Indicated \\
\hline $\begin{array}{l}\text { Total score of } \\
\text { the scale }\end{array}$ & Degree & $|\leqslant . \Lambda|$ & 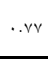 & r..r. & .991 & $11.0 \mathrm{~V}$ & $\%$ \% & $r .0 \varepsilon$ & Indicated \\
\hline
\end{tabular}

* Tabular value $(\mathrm{T})$ at significance level $(0.05)=1.796$

It is clear from Table (3) significant differences between that there are statistically the averages of the pre and Assiut Journal For Sport Science Arts 
post measurements at the level of the sensory perception of the visually impaired among the visually impaired. The value of (T) is greater than the tabular value at the significance level (0.05).

\section{Discussion of results}

It is clear from Table (2) that there are statistically significant differences between the averages of the pre and post measurements at the level of the body image scale for the visually impaired. The sample of the research was more than (T) value at the significance level (0.05) Use of the proposed program in the sense of mobility of visually impaired children.

In this regard, Iman Kashef, Reza Ashram (2010), notes that the individual's body and organic characteristics play an important role in shaping a fundamental aspect of the individual's concept of himself, known as the body image. (5: 7 ), and the perception of the individual from his body and the appearance of the organic and all that is felt in him as a person.

Blindness is visually impaired, and the sense of shyness is often felt because its disability has distorted its physical image. Blind people imagine that others think or stare at them and may take some measures or measures to hide the disorder that causes them to become preoccupied or disabled.

The view of the body is not the same through the different stages of life, in childhood, the perception of the body altogether, but in adolescence begins to look at parts of the body and compare with each other as compared with peers. (84:17)

Physical appearance is one of the main things that concern many people, and this is evident in the external perception of the social effects of the appearance and the internal view that refers to personal experiences or experiences that concern the appearance or what appears to the individual in fact, And the internal view in the broad sense is what Psychologists call it the so-called body image, which distinguishes between the inner view, and the external view is of great importance because we do not see ourselves in the way that others see us. (104: 26) $(98: 27)$ In the view of the researcher that there is a direct 
relationship between perception of the body image and behavior of the person, has added to that concept of the body image some psychologists have realized that the disruption of that image may occur at any period of growth of the individual or at any level in the cognitive development or integration of the person,

Early growth The injury of a particular part of the body is different from the disease or attracts the attention of others and gives an increasing psychological value to that part, which interferes with the system of body image.

Thus, the first hypothesis of the research, which states that there are statistically significant differences between the averages of the tribal and remote measurements in the level of the concept of body image in blind children from (4-6) of the research sample.

It is clear from Table (3) that there are statistically significant differences between the averages of the pre and post measurements at the level of the cognitive level of the visually impaired among the visually impaired. The sample value (T) was greater than the tabular value at the significance level (0.05) To use the proposed program in the sense of mobility of visually impaired children.

The researcher considers that sensory perception is one of the most important aspects of a child's life. It reflects the relationship between the cognitive, motor and psychological aspects, so it is necessary to improve these aspects in the child so that he can interact with the environment in performing the various activities required.

There are many different ways through which to develop the sense of movement in the child, including small games, which is one of the most prevalent methods in the world of childhood, a characteristic of motor activity. (45:24)

The researcher attributed this to the fact that the program was prepared in the sense of the sense of movement contained special games to train the senses to develop the discrimination of children, especially the sense of touch, because of the link hand movement, which is linked to the mind and help, 
And gave full freedom to play balls, playing ball at different sizes and weights and colors and this increased the sense The child was given the ball, and provided an atmosphere of fun and pleasure and desire to work, which increased the children's demand for games and the program was prepared to take care of exercises and games between the arms legs and legs movement and the exercises (jumping place, glove, jump applause) for blind children mobility programs over time as the kinetic susceptibility of children to evolve as a result of the gradual and diligent learning.

Thus, the second hypothesis of the research, which states that there are statistically significant differences between the averages of the pre and post measurements in the level of sensory perception of blind children from (4-6) of the research sample.

\section{Conclusions}

- The proposed program using the sense of kinetic program led to the development of the concept of the body image of the visually impaired child.
- The proposed program using the sense of kinetic program led to the development of sensory perception in the visually impaired child.

\section{Recommendations}

- Use the proposed program because of its positive impact on the level of development of the concept of body image and sensory perception of children with visual impairment.

- Expanding the construction of motor and psychological programs for visually impaired children.

- Conduct more studies on the psychological and physical characteristics of visually impaired children

\section{References}

\section{1 - Abdul Hakim bin Jawaad}

rain: Percentage of Obesity within students of Alnor Institutes with visual disabilities in Saudi Arabia, Scientific Journal of Education, No. 13, July, 2004.

2- Abdul Rahman Ibrahim, Ahmed Hussein El-Laqqani: Education of the Blind, Dar Alam Books, Cairo, 2003

3- Ahmed Mohamed Maher, Ahmed Mohamed Adam: Physical Education for the Blind, Anglo-Egyptian Library, Cairo, 2005 
4- Ahmed Mohamed Adam "Developed a curriculum for sports education for the blind (9-12 years), MA, Faculty of Physical Education for Boys, Helwan University, 2001.

\section{5- Ahmed Mahmoud Ali}

Shahda: Effect of a program using the exercises specific to the sense of consciousness the dynamic level of performance of the long jump for the blind in the basic education, Master, Faculty of Physical Education, Mansoura University, 2005

6- Awataf Ali Ibrahim, Manal Abdel Hadi El-Hindi: Children with Visual Disabilities, Dar Al-Fikr AlArabi, Cairo, 2006

7 - Hussein Ali Fayed: Body image, social anxiety and anorexia among adolescent females, Egyptian Journal of Psychological Studies, (23), Volume 31, Cairo, 2004.

8- Faraj Abdel-Qader Taha, Shaker Attia Kandil, Hussein Abdel- Qader Mohammed, Mustafa Kamel AbdelFattah, Encyclopedia of Psychology and Psychoanalysis, Dar Al-Wefaq for Printing and Publishing in Assiut, 2005.

\section{9- Fatima Fawzi El Sayed:}

Using Braille to learn the prepayment competition for blind students in the preparatory stage, the 4th international scientific conference of women's sport "The topic of women and children a futuristic vision from a mathematical perspective - Alexandria University, 2004.

10- Fayed Ali Fayed: Effect of a special training program for the development of some basic movements for the blind. Master Thesis, Faculty of Physical Education for Boys, Alexandria University, 2001.

\section{1- Ibrahim Mohamed}

Shaer: Education of the visually impaired, founded, strategies and methods, Arab Thought House, Cairo, 2009

\section{2- Iman Fouad Kashif, Reza}

Ibrahim Ashram: A measure of the body image of the visually impaired, the Modern Book House, Cairo, 2010.

\section{3- Iqbal Ibrahim Makhlouf:} Social Welfare, Services for the Disabled, Dar Al Maarif 
University, I 5, Alexandria, 2004.

14- Jihan Abdel-Fattah Shafiq "Effect of a proposed motor program on the development of adaptive behavior and kinetic growth of children from 6-9 years, MA, Faculty of Physical Education for Girls, Cairo, Helwan University, 2001

15- Manar Hassan Shaheen:

Effect of both the kinetic story and some types of gymnastics on the imagination and perception of motor sense and knowledge of blind children, $\mathrm{PhD}$ thesis, Faculty of Physical Education for Boys, Alexandria University, 2002

\section{6- Mohamed Al-Shabrawy}

Anwar: The relationship of body image to some variables of personality in adolescents, Journal of the Faculty of Education, Zagazig University, 2001.

\section{7- Mohamed El Sayed}

Abdel Razek: Effectiveness of a learning program by playing on some aspects of motor behavior of children with visual disabilities from 9-12 years, Master Thesis, Faculty of Physical Education,

Mansoura University, 2012

18- Mohamed Ibrahim

Ghoneim: The Effectiveness of a Program for the Development of Some Life Skills in Blind Children in Kindergarten, MA Thesis, Institute of Educational Studies, Cairo University, 2007 19- Mohammed Kamel Afifi: Physical Education of the Disabled between Theory and Practice, Dar Hira, Cairo, 2001.

20-Mohamed Sayed Fahmy: Social Behavior of the Disabled, Dar Al-Maarifah AlJami'a, Alexandria, 2001.

21- Najla Fathi Khalifa, A proposed motor education program for the development of basic motor skills for visually impaired children, preschool, master's thesis, Faculty of Physical Education for Girls, Alexandria University, 2002

22- Osama Riyad: Sports of the Disabled, Medical and Physical Basis, Dar Al-Fikr AlArabi, Cairo, 2005

23- Shaima Hassan El-Leithi, and Mervat Ali Selim The impact of a proposed 
educational program for the implantation of crawling on the abdomen for sensory-motor cognition for the blind "Experimental Study", Scientific Journal of Physical Education and Sports, Alexandria University, 4th Issue, January 2003.

24-Shroff, H. (2004): An Examination of Peer-Related Risk and Protective Factors for Body Image Disturbance and Disordered Eating Among Adolescent Girls, Diss from 2004
25-Siegel, J. (2002): Body Image Change and Adolescent Depressive Symptoms, Journal of Adolescent Research, V. 17, N. 1, P. $27-41,2002$

26-Small, K. and E Gallery (2001): Addressing Body Image, Self-Esteem, and Eating Disorders, A Peer Reviewed Journal, V. 2, N. 2:from

\section{7- Zeinab Mahmoud} Choucair: Battery diagnosis of cognitive sense of the blind in the Arab environment, the Anglo-Egyptian Library, 2011. 